\title{
Frequency of Ponticulus Posticus, Sella Turcica Bridge and Clinoid Enlargement in Cleft Lip and Palate Peruvian Patients: A Comparative Study with Non-Cleft Patients
}

\author{
Frecuencia de Ponticulus Posticus, Puente Selar y Alargamiento Clinoideo en Pacientes \\ Peruanos con Labio y Paladar Fisurado: Un Estudio Comparativo con Pacientes No-Fisurados
}

Iván E. Pérez ${ }^{* * * *}$ \& Allison K. Chávez ${ }^{* * * *}$

PÉREZ, I. E. \& CHÁVEZ, A. K. Frequency of Ponticulus posticus, Sella turcica bridge and clinoid enlargement in cleft lip and palate Peruvian patients: A comparative study with non-cleft patients. Int. J. Morphol., 33(3):895-901, 2015.

SUMMARY: The aims of this study were to determine the frequency of the Ponticulus posticus (PP) in the $\mathrm{C} 1$ vertebra and the Sella Turcica Bridge (STB) and Clinoid enlargement (CLEN) variants in two samples of Peruvian cleft lip and palate patients (CLP), determine if there are significant differences between sexes and compare the results with two samples of non-cleft controls. The digital images of the lateral cephalometric radiography of 163 and 150 CLP patients were utilized to determine the frequency of PP and, STBCLEN respectively. The controls were composed of 1056 and 417 radiography of non-cleft patients. The chi-square statistic was utilized to determine if there were significant differences between genres for the CLP patients, and between the CLP and control samples. The confidence level was set at $\mathrm{p}<0.05$. The frequency of PP (partial and complete) in CLP patients was $11.04 \%$ (18 cases) and $6.13 \%$ (10 cases) respectively; both of them were more frequent in males and there were no significant differences between sexes and between the CLP and control groups ( $\mathrm{p}>0.05$ ). The frequency of STB and CLEN in CLP patients was $6 \%$ (9 cases) and $8.7 \%$ (13 cases) respectively; both of them were more frequent in males and there were no significant differences between sexes and between the CLP and control samples for the STB ( $p>0.05)$. The frequency of CLEN was significantly lower $(p<0.05)$ in the cleft group and in the female cleft group when compared to the control group. The frequencies of the Ponticulus Posticus, Sella Turcica Bridge and Clinoid Enlargement were similar to the control group and should not be considered as Cleft Lip and Palate associated anomalies; the frequency of the Clinoid Enlargement was significantly lower in cleft patients and this could be confirmed through studies centered on the Clinoid apophysis.

KEY WORDS: Cervical Vertebrae/radiography; Cervical Atlas/radiography; Sella Turcica/radiology; Cleft Lip/ radiography; Cleft Palate/radiography; Cleft Palate/statistics and numerical data; Cephalometry.

\section{INTRODUCTION}

The frequencies of Ponticulus Posticus (complete and partial) in the Atlas vertebrae; the Sella Turcica Bridge and the Clinoid Enlargement in Peruvians were determined in two distinct studies (Pérez et al., 2013, 2014); those frequencies and the samples where they come from could be utilized as control groups that can be matched with other samples of patients with specific conditions such as Cleft lip and palate.

The Cleft lip and/or palate (CLP) is considered to be the most common congenital anomaly present in the craniofacial region (Alkofide, 2008); it has been reported as a solitary finding, or associated with other malformations in over 250 syndromes (Horswell, 1991) that occurs particularly in the central nervous, cardiac, and musculoskeletal systems (Milerad et al., 1997; Horswell).

There have been conflicting reports regarding the incidence of associated anomalies in CLP patients (Horswell); for example, a common finding is that children with CLP have more prevalence of cervical vertebrae anomalies (CVA) than the control groups (Osborne et al., 1974; Sandham, 1986; Horswell; Lima et al., 2009; Srivastava et al., 2014); and although most CVA are asymptomatic these can be detected and investigated by plain radiography (Manaligod et al., 1999), especially by the la-

\footnotetext{
* Centro de Radiología Oral y Maxilofacial (CEROMA), Lima-Perú.

** Centro para la Investigación de las Disarmonias Dentofaciales (CIDDENT), Lima-Perú.

**** Departamento de Clínica Estomatológica, Facultad de Estomatología, Universidad Peruana Cayetano Heredia, Lima, Perú.
} 
teral cephalometric radiography taken before the orthodontic treatment (Srivastava et al.).

Since CLP occurs in connection with a number of more generalized and less readily noticeable anomalies, it is important to draw attention at the time of the initial diagnosis of CLP to the possibility of other deformities (Sandham) for the following reasons: (1) it will improve screening and evaluation mechanisms in departments dealing with cleft palate and other craniofacial anomalies; (2) it will also help to provide an optimal comprehensive care because early identification of problems may be made; proper consultations obtained and appropriate treatment planning performed (Horswell), and (3) the corroboration of CLP with associated anomalies may lead to a greater understanding of the embryonic phenomena underlying the malformation process (Horswell; Lima et al.).

The frequency of the Ponticulus posticus (complete or partial) in the Atlas vertebra and STB - CLEN variants of the Sella Turcica has not been investigated before and, therefore, the aims of this study were to determine the frequency of the Ponticulus posticus and the Sella Turcica Bridge and Clinoid enlargement variants in a sample of Peruvian cleft lip and palate patients, determine if there are significant differences between sexes and compare the results with the samples of the studies of PP, STB and CLEN realized in non-cleft Peruvian patients.

\section{MATERIAL AND METHOD}

The lateral cephalometric radiography of CLP patients (unilateral and bilateral cleft lip and palate) taken as a part of a radiographic orthodontic protocol in two oral radiology centers, between 2008-2013 (center 1, plain film radiography) and between 2013-2014 (center 2, digital radiography), were retrieved and visualized using the ROMEXIS ${ }^{\circledR}$ software 3.6.0.R (Planmeca Co., Helsinski, Finland).

A set of 300 lateral cephalometric radiographs of CLP patients were retrieved; two distinct samples were utilized to determine the PP and the STB-CLEN frequencies because the variations manifests in distinct areas and the exclusion criteria varied for each one. The exclusion criteria applied in the two samples were the poor quality of the image and the presence of craneofacial syndromes; for the PP sample, the projection of the mastoid apophysis over the posterior arch of atlas was included as exclusion criteria.

The samples utilized to determine the frequency of PP and STB-CLEN (Pérez et al., 2013, 2014) were used as control groups to compare the frequencies of PP and STB-CLEN between CLP and non-CLP patients. The PP controls were composed of 1056 lateral cephalometric radiography, $56.7 \%$ of female and $43.3 \%$ of male; the age range was 3-56 years with a mean and standard deviation of $14.05 \pm 7.43$ years; the STB-CLEN controls were composed of 417 lateral cephalometric radiography, $57.3 \%$ of female and $42.7 \%$ of male; the age range was $5-53$ years with a mean and standard deviation of 14.73 \pm 7.83 .

The frequencies of PP and STB-CLEN in CLP patients were determined in each sample. The $\mathrm{X} 2$ statistics were utilized to determine if there are significant differences between sexes in the CLP samples and utilized, as well, to determine if there are significant differences in the frequencies of PP and STB-CLEN between CLP and nonCLP patients. The confidence level was set at $\mathrm{p}<0.05$.

The criteria for determining the PP, STB and CLEN were the same utilized in previous publications (Pérez et al., 2013, 2014):

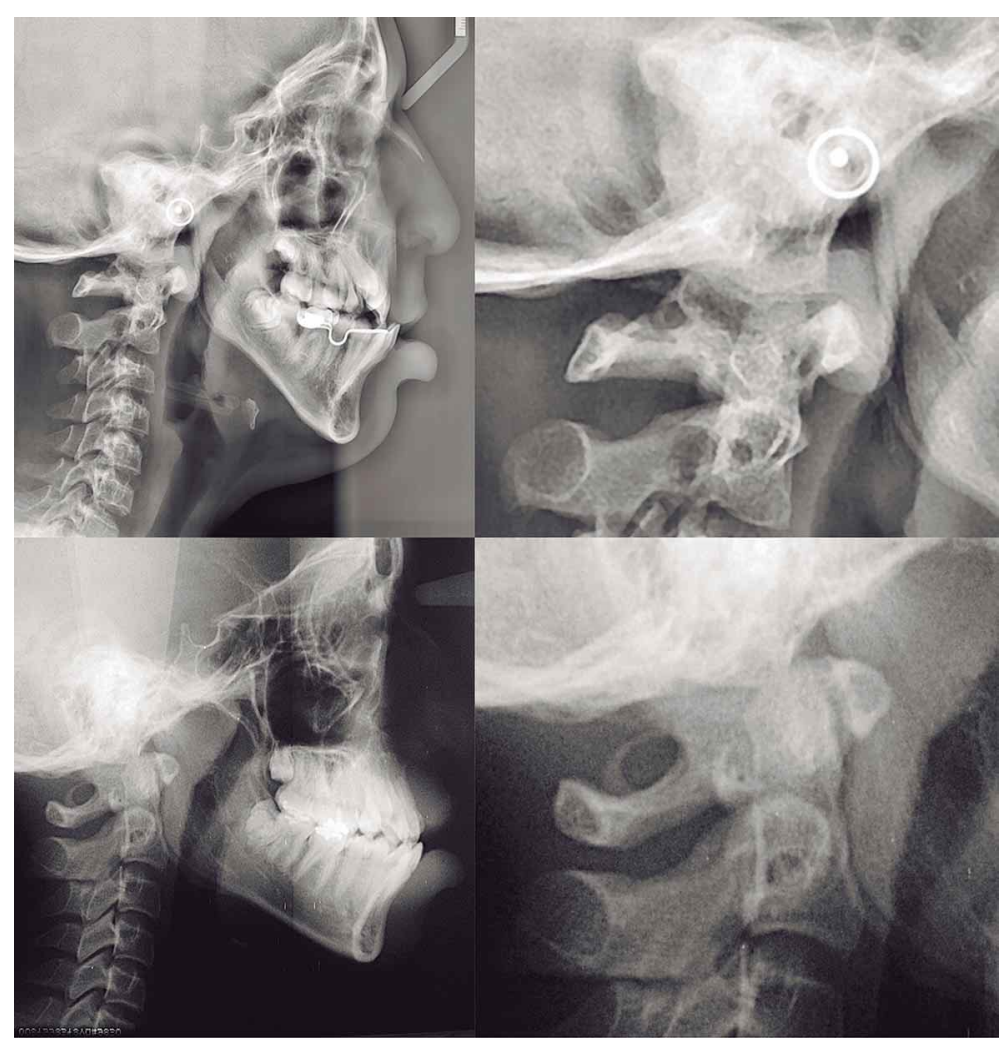

Fig. 1. Complete Ponticulus posticus. Notice the bony bridge between the articular process and the posterior arch in the atlas. 


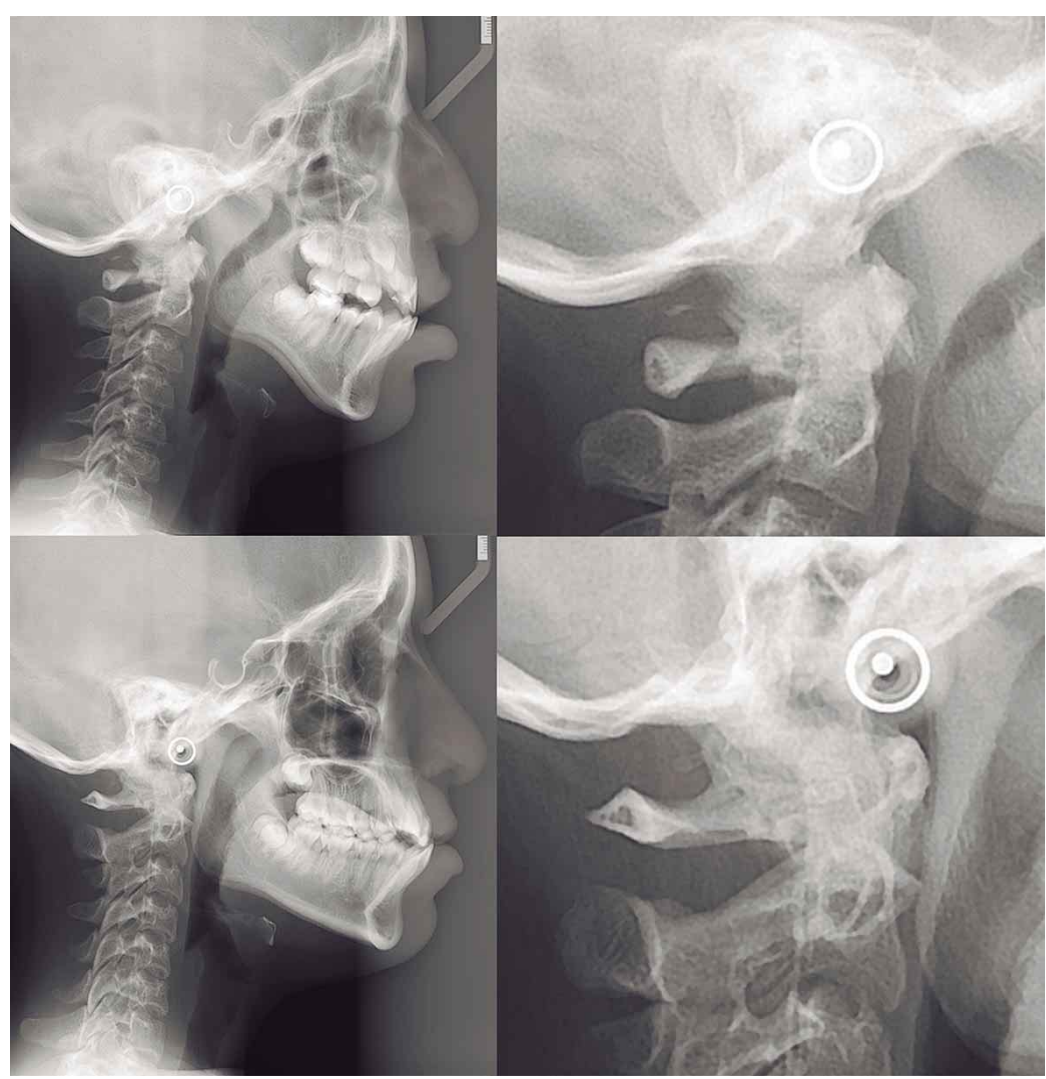

Fig. 2. Partial Ponticulus posticus. Notice the fainted incomplete bony ring from the articular process.

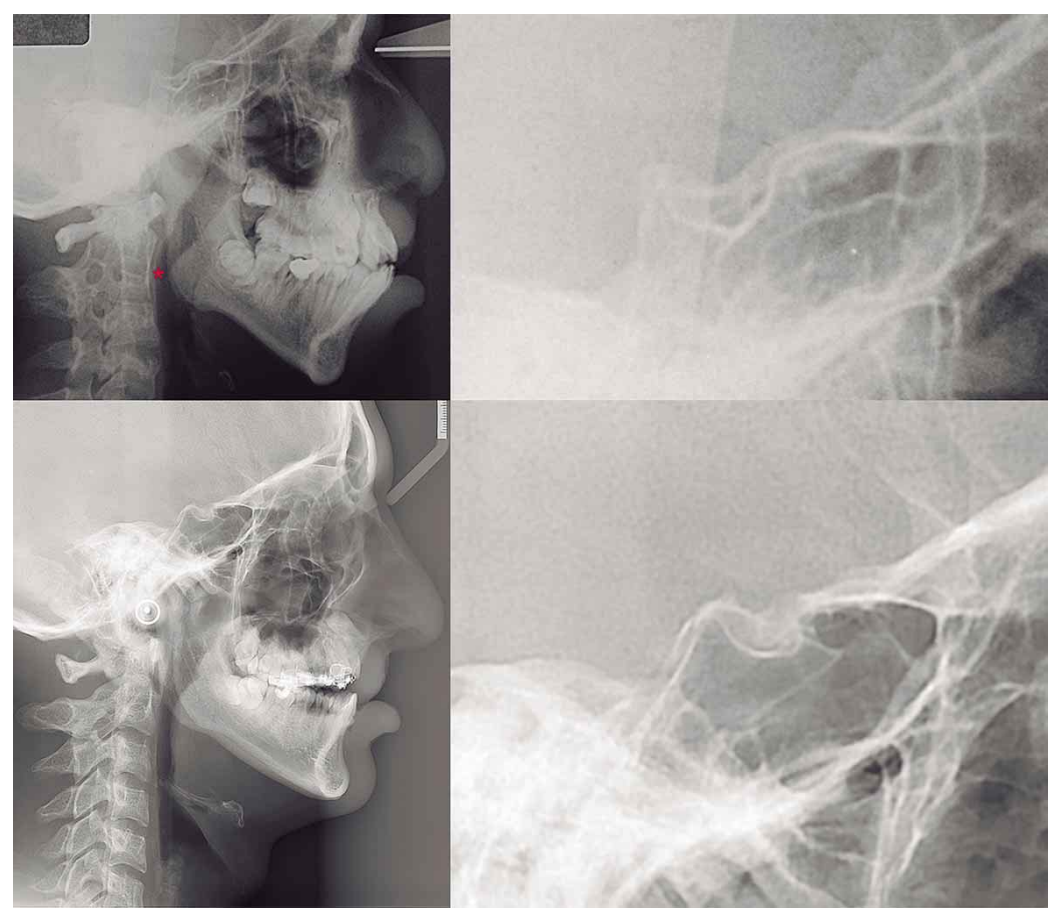

Fig. 3. Sella Turcica Bridge (STB). Notice the complete bony bar between the Clinoid processes with an appearance of enclosed sella. *Notice the fusion between the bodies and spinous processes of $\mathrm{C} 2$ and $\mathrm{C} 3$.
- Complete Ponticulus Posticus, when a complete bony bridge between the superior articular process and posterior arch of the Atlas was observed (Fig. 1).

- Partial Ponticulus Posticus, when the ossified portion in more than one half the hemisphere or the posterior tip of the ossified portion was hanging inferiorly, exhibiting two thirds or more of a foramen created by the bony bridge (Fig. 2).

- Sella Turcica Bridge, presence of a continuous bony bar between the anterior and posterior Clinoid processes with a delimited round cavity below and the appearance of a separate enclosed hypophysial fossa (Fig. 3).

- Clinoid Enlargement, presence of an enlargement of the anterior or posterior Clinoid processes that surpasses the Sella (S) cephalometric point (Fig. 4).

To determine the intraexaminer agreement in the identification of PP and STB-CLEN, 19 lateral cephalometric radiographs were re-evaluated by the maxillofacial radiologist two weeks after the analysis; Kappa coefficient value was 0.81 and 0.64 which means a substantial strength of agreement (Sim \& Wright, 2005).

\section{RESULTS}

After the application of the exclusion parameters criteria, two samples of 163 and 150 lateral cephalometric radiographs were used to determine the frequency of PP and STB-CLEN in CLP patients respectively.

The sample utilized to determine the frequency of PP (complete and partial) in CLP patients was comprised of 163 lateral cephalometric radiographs; $42.9 \%$ of female and $57.1 \%$ of male; the age range was $6-40$ years with a mean and standard deviation of 11.3 \pm 4.2 years of age. The frequency of PP in CLP patients was $17.18 \%$ ( 28 cases); the frequency of partial PP was $11.04 \%$ (18 cases) and the frequency of complete PP was $6.13 \%$ (10 cases). The PP was more 


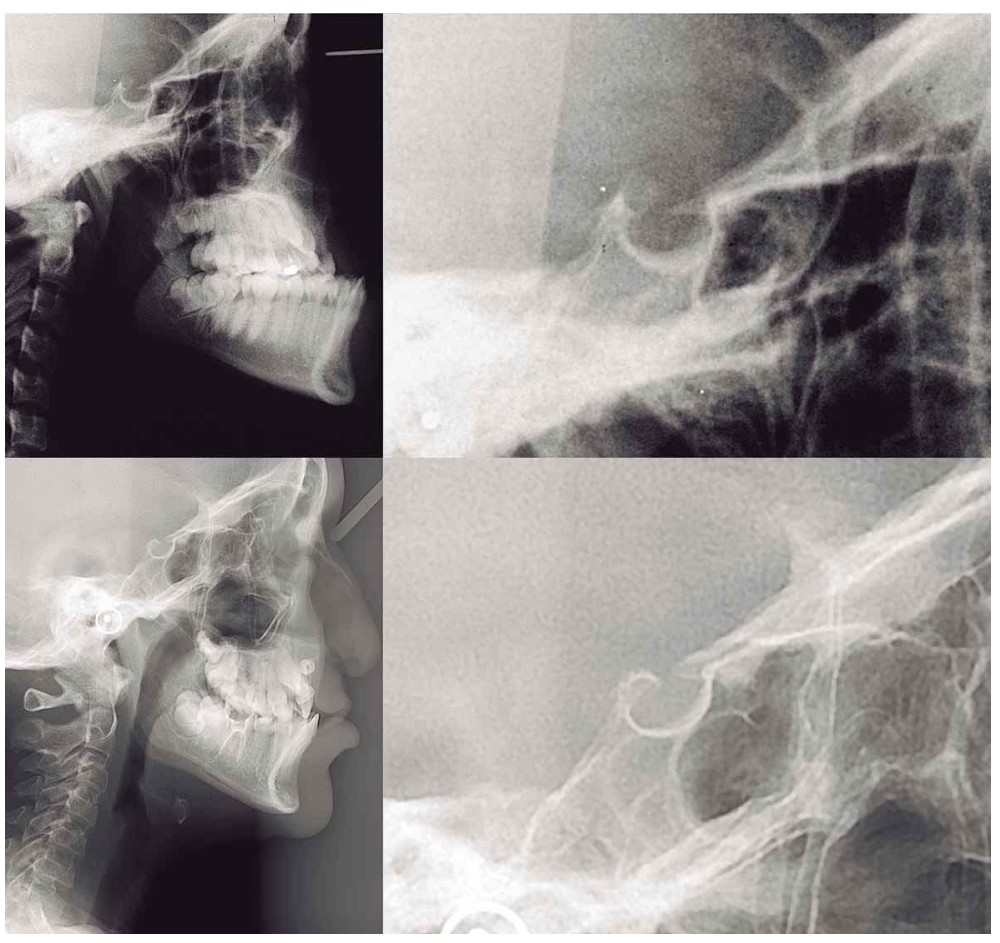

Fig. 4. Clinoid Enlargement (CLEN). Notice the enlargement of the Clinoid apophysis that surpasses the $\mathrm{S}$ (Sellae) point.

frequently found in males with $80 \%$ of cases in the complete PP and $66.7 \%$ of the cases in the partial PP. There were no significant differences in the frequency of PP (total and partial) in both sexes according to the results of the $\mathrm{X} 2$ test ( $\mathrm{p}>0.05)$. When comparing the
CLP group with the control group, the frequency of complete PP was lower in the CLP group $(6.1 \%$ against $8.7 \%)$ whereas the frequency of partial PP was similar in both groups (11.04\% against $11.08 \%$ ), the $\mathrm{X} 2$ value was not significant $(\mathrm{p}>0.05)$ (Table I).

The sample utilized to determine the frequency of STB and CLEN in CLP patients was comprised of 150 lateral cephalometric radiographs; $44 \%$ of female and $56 \%$ of male; the age range was 6-40 years with a mean and standard deviation of 11.2 \pm 4.2 years of age. The frequency of STB and CLEN in CLP patients was $6 \%$ (9 cases) and 8.7\% (13 cases) respectively. Both findings were more frequent in males with $66.7 \%$ for STB and $61.5 \%$ for CLEN. There were no significant differences in the frequency of STB and CLEN between both sexes in the CLP patients according to the results of the $X 2$ test $(p>0.05)$. In the comparison of the CLP with the control group, the differences in the frequency of STB were non-significant $(p>0.05)$ between the cleft and non-cleft patients (6\% against $4.3 \%)$. The frequency of CLEN was significantly lower $(p<0.05)$ in the CLP group and in the female CLP group when compared the control group (8.7\% against $16.3 \%$ and $3.3 \%$ against $10.31 \%$ respectively) (Table II).

Table I. Frequency and distribution of Ponticulus posticus (complete and partial) in Peruvian CLP and in non-cleft patients.

\begin{tabular}{lcccccccc}
\hline & \multicolumn{3}{c}{ Ponticulus Posticus in cleft patients*, $\dagger$} & \multicolumn{3}{c}{ Ponticulus Posticus in non-cleft patients $\dagger$} \\
\cline { 2 - 8 } & Complet e (\%) & Partial (\%) & No & Total & Complet e (\%) & Partial (\%) & No & Total \\
\hline Female & $2(1.22)$ & $6(3.68)$ & 62 & 70 & $39(3.69)$ & $62(5.87)$ & 498 & 599 \\
Male & $8(4.91)$ & $12(7.36)$ & 73 & 93 & $53(5.02)$ & $55(5.21)$ & 349 & 457 \\
Total & $10(6.13)$ & $18(11.04)$ & 135 & 163 & $92(8.71)$ & $117(11.08)$ & 847 & 1056 \\
\hline
\end{tabular}

* Non significant differences between genres $(\mathrm{p}>0.05)$ according to the $\mathrm{X} 2$ test.

$\dagger$ Non significant differences between cleft and non-cleft samples ( $p>0.05)$ according to $\mathrm{X} 2$ test.

Table II. Frequency and distribution of STB and CLEN in Peruvian CLP and in non-cleft patients.

\begin{tabular}{lcccccccc}
\hline & \multicolumn{3}{c}{ STB and CLEN in cleft patients* } & \multicolumn{3}{c}{ STB and CLEN in non-cleft patients $\dagger$} \\
\cline { 2 - 8 } & STB $\dagger(\%)$ & CLEN $*(\%)$ & No & Total & STB (\%) & CLEN C\%) $_{c}$ No & Total \\
\hline Female & $3(2)$ & $5(3.3)$ & 58 & 66 & $8(191)$ & $43(10.31)$ & 188 & 239 \\
Male & $6(4)$ & $8(5.3)$ & 70 & 84 & $10(2.39)$ & $25(5.99)$ & 143 & 178 \\
Total & $9(6)$ & $13(8.7)$ & 128 & 150 & $18(4.3)$ & $68(16.3)$ & 331 & 417 \\
\hline
\end{tabular}

* Non significant differences between genres ( $>0.05$ ) according to $\mathrm{X} 2$ test.

$\dagger$ Non significant differences between cleft and non-cleft samples ( $p>0.05)$ according to $\mathrm{X} 2$ test.

$\ddagger$ Significant differences between cleft and non-cleft samples in the general population and the female population according to $\mathrm{X} 2$ test $(\mathrm{p}<0.05)$. 


\section{DISCUSSION}

When investigating the craniofacial dysmorphology, it is tempting to make an association between two or more defects and link them to a common embryonic event. The presence of associated anomalies in cleft patients has been proposed as a malformation spectrum (Horswell) and linked to a common embryologic factor (Lima et al.) based on a fault(s) at cellular level in which disruption of mesenchymal development may lead to abnormal migration, induction, and or proliferation of embryonic tissues which can occur at sites distant from the palatal shelves, like the cervical spine or the sella turcica regions (Horswell).

Manaligod et al. stated that cervical spine anomalies often coexist with syndromic anomalies of the head and neck and emphasized that those anomalies should be detected by radiographic imaging as early as possible to optimize management and reduce the risk of neurologic injury (Ugar $\&$ Semb, 2001).

A common finding is that children with CLP have more prevalence of cervical spine anomalies (CSA) or cervical vertebrae anomalies (CVA), both terms are used in the literature, than the normal population (Srivastava et al.) and, to date, the significant association between CLP and CSA CVA (which includes vertebral fusions, posterior arch defects of the atlas and spina bifida among others) has been demonstrated in several case-control studies such as: (1) Horswell studied 468 North American cleft patients and found an incidence of $22 \%$ of CSA. (2) Lima et al. studied 300 Brazilian cleft patients and found a prevalence of $38.67 \%$ of CVA (fusion of vertebrae, spina bifida-dehiscenceoccipitalization of the Atlas and block fusion). (3) Sandham studied 105 Scottish cleft patients and found a prevalence of $13.3 \%$ (posterior arch deficiency-PAD and fusion of vertebrae). (4) Ugar \& Semb studied 611 Norwegian cleft patients and found a frequency of $18.2 \%$ of CVA (spina bifida, dehiscence, fusion of vertebrae and occipitalization). (5) Srivastava et al. studied 228 Indian cleft patients and found a frequency of $19.29 \%$ of CVA (spina bifida, dehiscence, fusion of vertebrae and occipitalization).

The frequency of PP (complete and partial), STB and CLEN in our sample of cleft patients were $6.13 \%, 11.04 \%$, $6 \%$ and $8.7 \%$ respectively with no significant differences between sexes and with the control groups of PP and STBCLEN ( $p>0.05$ ); however, the frequency of CLEN in CLP patients was significantly lower than the controls $(8.7 \%$ against 16.3\%) which might suggests that the CLP patients of the studied sample (Peruvians) would have a lower tendency to manifest the CLEN variant on the Sella Turcica; about this finding, we must consider that the present study is based on the description of the radiological appearance of the Clinoid apophysis tip, and the significant result concerning CLEN alongside with the questions of this finding should be tested in future studies.

In a literature review about PP (Elliott \& Tanweer, 2014), there were 22 papers about the frequency of PP on lateral radiography (until 2012) with a combined population of 14142 observations, a mean age of 34.2 years, $47.5 \%$ of female and $52.5 \%$ of male and an overall prevalence of PP of $16.2 \%, 9.9 \%$ (complete) and $7.7 \%$ (partial). Combining the cadaver, lateral radiography and CT studies, the overall point estimate of the prevalence of the anomaly was $18.1 \%$ (95\% CI: $15.7 \%-20.8 \%$ ) with non-significant differences in the prevalence found with those methods; also the point estimate of the prevalence in lateral radiography was $17.5 \%$ (95\% CI: $14.1 \%-21.5 \%)$. The frequency found in the present study for cleft patients and the frequency reported for noncleft patients lies in the confidence interval of the literature review, which would suggests that the presence of PP may not be related to specific ethnic groups and to CLP groups as well.

The frequency of the PP in CLP patients has not been studied before and our study represents the first attempt to determine the frequency of this anatomical variation, our results demonstrate that the frequency of PP is similar when contrasted to the control group and cannot be considered as an associated anomaly-variant of cleft patients like the CSA - CVA are (Horswell; Lima et al.; Sandham; Osborne et al.).

Brown \& Verheyden (2009) reported the complication of posterior fossa circulatory ischemic injury following cleft palate repair in a 1-year old boy with a nonimportant medical background aside from a suspicious Ponticulus posticus/Arcuate foramen in the Atlas vertebra. The authors stated that the presence of a PP in CLP individual should influence the patient positioning at the time of surgery because; traditionally, the surgical approaches of cleft repair start with a supine patient with the head on an adjustable rest and a roll placed under the shoulders with the neck in variable degrees of extension, and some surgeons prefer to operate with the neck in full extension, nearly to the point that the head is sitting in the surgeons lap and it is possible that such extension of the neck in combination with the PP could lead to bilateral occlusion of the vertebral artery and ischemic injury of the posterior fossa which could be a cause of death. Aside from this report and regardless of the statistical significance, the frequency of PP $(17.17 \%)$ is not uncommon (Perez et al.) or not rare (Elliott \& Tanweer) in both CLP and non-CLP patients and, consequently, the presence of a PP should be taken into consideration when 
planning the approach of any corrective surgery where the cervical extension of the patient is necessary.

Studies on the size of the sella turcica in cleft subjects have been lacking (Alkofide). The published analysis of the sella turcica morphology in cleft lip and palate patients was done by Nielsen et al. (2005) and Alkofide. Nielsen et al., conducted a study on radiographs of 40 Caucasian newborns with unilateral cleft lip and unilateral cleft lip and palate and concluded that approximately half of the subjects had deviations in the sella turcica morphology, with the most severe deviations occurring in UCLP subjects and that deviations in sella turcica morphology registered within and between groups may explain why a subset of cleft patients has occult midline, neural and learning deficiencies, and hypophyseal/endochrine and somatic growth problems; it must be noted that the authors did not specify what kind of sella turcica morphology deviations were found. Alkofide conducted a study on lateral radiographs of 95 Saudi cleft patients. The majority of the cleft group displayed an abnormal ST shape $(63.2 \%)$ compared with a normally shaped ST $(64.7 \%)$ in the non-cleft patients with significant differences between both groups; the morphological aberrations in cleft subjects were double contour of the floor, an irregular posterior wall, oblique anterior wall, STB, Pyramidal shape dorsum and more than one abnormality. The STB frequency was 2/190 in the control group and 1/95 in the cleft group (1.05\% in both groups), those frequencies are lesser than our results in the control and in the cleft group which were $4.3 \%$ and $6 \%$ respectively but the authors did not state if the STB alone was significant in the cleft group when compared with the control group, our results suggests that the relationship is not significant. The CLEN frequency was significantly lower $(\mathrm{p}<0.05)$ in the cleft patients and in the female cleft patients, and that represents an unreported finding that cannot be compared with the studies of Alkofide and Nielsen et al. because the term CLEN and the methodology to determine it, was coined after the date of those publications.

The frequency of CLEN in the CLP sample and in the female was significantly lower than the control group, and those findings could be confirmed by studies centered on the Clinoid apophysis. In the present study, the Clinoid enlargement (CLEN) represents a qualitative variable that depends on the position of the tip of the Clinoid apophysis (both) and their position relative to the Sella (S) point; on a deeper analysis we can describe two disadvantages such as: (a) no information about which Clinoid apophysis is enlarged, and (b) no further classification other than the presence of the finding; moreover, the interclinoid distance can be determined and compared in CLEN and non-CLEN cases for set a detailed classification of that variable in studies conducted in digital cephalometric radiography (preferably) due to the actual size (1:1 relationship) and the image enhancement tools available to digital radiography such as gray level transformation, image filtering and noise smoothing (Döler et al., 1991) which can be helpful to determine the exact location of the tips Clinoid apophysis.

The frequencies of Ponticulus Posticus (complete or partial) and Sella Turcica Bridge in the sample of Peruvian cleft patients were similar, with no significant differences, to the control group and consequently these anatomical variants should not be considered as CLP associated anomalies. The frequency of CLEN was significantly lower in cleft patients and should not considered as a CLP associated anomaly too but this finding could be confirmed through studies centered on qualitative and quantitative variables of the Clinoid apophysis.

PÉREZ, I. E. \& CHÁVEZ, A. K. Frecuencia de ponticulus posticus, puente selar y alargamiento clinoideo en pacientes peruanos con labio y paladar fisurado: un estudio comparativo con pacientes no-fisurados. Int. J. Morphol., 33(3):895-901, 2015.

RESUMEN: Los objetivos del estudio fueron determinar la frecuencia del Ponticulus Posticus (PP) y Puente selar - Alargamiento clinoideo (PS-AC) en dos muestras de pacientes Peruanos con fisura labiopalatina, junto con determinar si hay diferencias significativas entre sexos y comparar los resultados con dos muestras de controles sin fisura labiopalatina. Imágenes de radiografías cefalométricas laterales fueron utilizadas para determinar la frecuencia de PP $(n=163)$ y PS-AC $(n=150)$. Los controles estuvieron conformados por 1056 y 417 radiografías de pacientes sin fisura labiopalatina. La prueba chi-cuadrado fue utilizada para determinar si existen diferencias significativas entre los sexos de los pacientes con fisura labiopalatina, y también entre las muestras de fisura labiopalatina y los controles. El nivel de confianza se determinó en p $<0,05$. En pacientes con fisura labiopalatina, la frecuencia de PP (parcial y completo) fue de 11,04\% y 6,13\% respectivamente; fue más frecuente en hombres y no se encontraron diferencias significativas entre sexos y entre la comparación entre muestras ( $\mathrm{p}>0,05)$. La frecuencia de PS y AC fue de $6 \%$ y $8,7 \%$, respectivamente; ambos fueron más frecuentes en hombres y no se encontraron diferencias significativas entre sexos; no se encontró diferencias significativas entre las muestras de fisura labiopalatina y los controles en el caso del PS. La frecuencia de AC fue significativamente menor en el grupo de fisura labiopalatina y en las mujeres con fisura labiopalatina respecto a la población sin fisura labiopalatina ( $\mathrm{p}<0,05)$. Las frecuencias de PP y PS fueron similares a las del grupo control y no deberían ser consideradas como anomalías asociadas a la fisura labiopalatina; la frecuencia del AC fue significativamente menor en pacientes con fisura labiopalatina, y tampoco debería considerarse como una anomalía asociada; este hallazgo podría ser confirmado en futuros estudios centrados en las apófisis clinoides.

PALABRAS CLAVE: Vértebras cervicales/radiografía; Atlas cervical/radiografía; Silla Turca/radiología; Labio fisurado/radiografía; Paladar fisurado/radiografía; Cefalometría. 


\section{REFERENCES}

Alkofide, E. A. Sella turcica morphology and dimensions in cleft subjects. Cleft Palate Craniofac. J., 45(6):647-53, 2008.

Brown, M. \& Verheyden, C. Posterior fossa infarction following cleft palate repair and the arcuate foramen. Plast. Reconstr. Surg., 124(5):237e-9e, 2009.

Döler, W.; Steinhöfel, N. \& Jäger, A. Digital image processing techniques for cephalometric analysis. Comput. Biol. Med., 21(1-2):23-33, 1991.

Elliott, R. E. \& Tanweer, O. The prevalence of the ponticulus posticus (arcuate foramen) and its importance in the GoelHarms procedure: meta-analysis and review of the literature. World Neurosurg., 82(1-2):e335-43, 2014.

Horswell, B. B. The incidence and relationship of cervical spine anomalies in patients with cleft lip and/or palate. J. Oral Maxillofac. Surg., 49(7):693-7, 1991.

Lima, M. C.; Franco, E. J.; Janson, G.; Carvalho, I. M.; Santos, C. F. \& Capelozza, A. L. Prevalence of upper cervical vertebrae anomalies in patients with cleft lip and/or palate and noncleft patients. Cleft Palate Craniofac. J., 46(5):481-6, 2009.

Manaligod, J. M.; Bauman, N. M.; Menezes, A. H. \& Smith, R. J. Cervical vertebral anomalies in patients with anomalies of the head and neck. Ann. Otol. Rhinol. Laryngol., 108(10):925-33, 1999.

Milerad, J.; Larson, O.; PhD, D.; Hagberg, C. \& Ideberg, M. Associated malformations in infants with cleft lip and palate: a prospective, population-based study. Pediatrics, 100(2 Pt. 1):180-6, 1997.

Nielsen, B. W.; Mølsted, K. \& Kjaer, I. Maxillary and sella turcica morphology in newborns with cleft lip and palate. Cleft Palate Craniofac. J., 45(6):610-7, 2005.

Osborne, G. S.; Pruzansky, S. \& Koepp-Baker, H. Upper cervical spine anomalies and osseous nasopharyngeal depth. J. Speech Hear. Res., 14(1):14-22, 1974.

Pérez, I. E.; Chávez, A. K. \& Ponce, D. Frequency of ponticulus posticus in lateral cephalometric radiography of peruvian patients. Int. J. Morphol., 32(1):54-60, 2014.

Pérez, I. E.; Chávez, A. K. \& Ponce, D. Frequency of sella turcica bridge and clinoid enlargement in lateral cephalometric plain film radiography from peruvians. Int. J. Morphol., 31(2):3737, 2013.

Sandham, A. Cervical vertebral anomalies in cleft lip and palate. Cleft Palate Craniofac. J., 23(3):206-14, 1986.
Sim, J. \& Wright, C. C. The kappa statistic in reliability studies: use, interpretation, and sample size requirements. Phys. Ther., 85(3):257-68, 2005.

Srivastava, M.; Aggarwal, A.; Batra, P.; Datana, S.; Kumar, P. \& Macrcusson, K. A. Association of cervical vertrebra anomalies with cleft lip and palate. J. Cleft Lip Palate Craniofac. Anom., 1(1):43-7, 2014.

Ugar, D. A. \& Semb, G. The prevalence of anomalies of the upper cervical vertebrae in subjects with cleft lip, cleft palate, or both. Cleft Palate Craniofac. J., 38(5):498-503, 2001.

\author{
Correspondence to: \\ Iván Pérez \\ Centro para la Investigación de las Disarmonías \\ Dentofaciales (CIDDENT) \\ Lima \\ PERÚ
}

Email: iepl76@yahoo.com

Received: 29-10-2014

Accepted: 01-06-2015 